\title{
MLANA wt Allele
}

National Cancer Institute

\section{Source}

National Cancer Institute. MLANA wt Allele. NCI Thesaurus. Code C54313.

Human MLANA wild-type allele is located in the vicinity of 9p24.1 and is approximately 20 $\mathrm{kb}$ in length. This allele, which encodes melanoma antigen recognized by T-cells 1 protein, may be involved in the regulation of melanin biosynthesis. Aberrant expression of the gene may play a role in melanoma. 